\title{
ASERTIF TRAINING MENINGKATKAN KOMUNIKASI INTERPERSONAL SISWA SMKN X
}

\author{
Astinah \\ astinahamirasyah@yahoo.com
}

\begin{abstract}
This research is an experimental research with the aim of providing treatment in the form of assertive training interventions to improve interpersonal communication skills of class X students majoring in Marketing at SMKN X. This research uses a quasi experimental design with nonrandomized pretest-posttest control group design. The data are collected through observation, interviews, FGD, and interpersonal communication scale (Puspitasari, 2012). The data are analyzed by using SPSS 16.0 for windows with non-parametric statistical analysis paired sample t-test. The results showed that assertive training improved students' interpersonal communication skills. This can be observed from the statistical analysis between pre-test and post-test obtained $p=0,000(p<0.05)$. In addition, an increase also occurred in the results of statistical analysis between post test and follow up with a value of $p=0,000(p<0.05)$.
\end{abstract}

Keywords: Interpersonal Communication, Assertive, Assertive Training, SMKN Students

\begin{abstract}
Abstrak
Penelitian ini merupakan penelitian eksperimen dengan tujuan memberikan perlakuan berupa intervensi pelatihan asertif untuk meningkatkan keterampilan komunikasi interpersonal siswa kelas $\mathrm{X}$ jurusan Pemasaran pada SMKN X. Penelitian ini menggunakan desain quasi experimental dengan nonrandomized pretest-posttest control group design. Pengumpulan data melalui observasi, wawancara, FGD, dan skala komunikasi interpersonal (Puspitasari, 2012). Analisis data menggunakan SPSS 16.0 for windows dengan analisis statistik non
\end{abstract}


parametrik paired sample t-test.Hasil penelitian menunjukkan bahwa pelatihan asertif meningkatkan keterampilan komunikasi interpersonal siswa. Hal demikian dapat dilihat dari analisis statistik antara pre test dan post test diperoleh $\mathrm{p}=0,000$ $(\mathrm{p}<0,05)$. Selain itu, peningkatan juga terjadi pada hasil analisis statistik antara post test dan follow up dengan nilai $\mathrm{p}=0,000(\mathrm{p}<0,05)$.

Kata Kunci: Komunikasi Interpersonal, Asertif, Pelatihan Asertif, Siswa SMKN

\section{PENDAHULUAN}

Sekolah kejuruan merupakan sekolah yang fokus pada peningkatan keterampilan siswa pada suatu bidang tertentu dalam mempersiapkan lulusannya untuk siap bekerja. SMKN X sebagai salah satu SMKN dengan empat jurusan yaitu jurusan akuntansi, administrasi perkantoran, busana butik dan pemasaran. Kompetensi di tiap jurusan berbeda satu sama lain. Pada jurusan pemasaran dimana menuntut siswa terampil dalam menjalin kerja sama dengan orang lain dan cakap berinteraksi dengan sesama individu serta kelompok khususnya dalam bidang bisnis. Siswa pemasaran dituntut untuk kompeten dalam berinterkasi secara efektif dengan lingkungan sosial dan terampil dalam menempatkan diri sebagai cerminan dalam pergaulan yang positif dan bekerja sama dalam menyelesaikan permasalahan.

Pencapaian kompetensi tersebut dengan meningkatkan keterampilan yang dimiliki oleh siswa. Namun mencapai hal tersebut bukan menjadi suatu hal yang mudah bagi siswa kelas X Pemasaran. Siswa mengeluhkan bahwa hubungan antar teman kelas menjadi tidak kondusif disebabkan karena adanya beberapa kelompok kecil dalam kelas yang menjadikan siswa tidak saling mengenal lebih dekat satu sama lain. Hal tersebut dianggap menjadi pemicu komunikasi antar pribadi siswa menjadi terhambat. Namun hal demikian bukanlah satu-satunya kendala akan tetapi beberapa siswa juga cenderung diam karena kurang mampu mengutarakan perasaan, pikiran maupun pendapat saat berinteraksi dengan teman baik saat pelajaran berlangsung maupun saat diluar jam pelajaran. Permasalahan yang terjadi di kelas X Pemasaran menggambarkan bahwa komunikasi antar siswa 
menjadi tidak berjalan dengan lancar menjadikan para siswa sulit mengasah keterampilan untuk mencapai kompetensinya sebagai siswa SMKN khususnya jurusan pemasaran.

Kondisi demikian menghambat proses pembelajaran serta interkasi pertemanan diantara siswa. Siswa tidak saling mendukung teman saat belajar seperti mengganggu teman saat presentasi, berkata kasar kepada teman dan guru, sebaliknya beberapa siswa tidak percaya diri mengungkapkan pendapatnya saat presentasi maupun saat diskusi kelompok. Kondisi demikian, menghambat siswa dalam mengembangkan keterampilannya beinteraksi dengan orang lain di luar sekolah seperti saat magang. Komunikasi interpersonal yang kurang pada siswa $\mathrm{X}$ Pemasaran menjadikannya tidak komepeten di lapangan. Komunikasi interpersonal menjadi suatu hal yang sangat penting untuk menjalin hubungan yang baik dengan orang lain dan mengenali diri sendiri.

Menurut Suranto (2011) bahwa komunikasi intrepersonal adalah proses penyampaian dan penerimaan pesan antara pengirim pesan (sender) dan penerima (receiver) baik secara langsung maupun tidak langusng. Hal demikian sejalan dengan pendapat Devito (Liliweri, 1996) bahwa komunikasi interpersonal adalah penyampaian pesan oleh satu orang dan penerimaan pesan oleh orang lain atau sekelompok kecil orang, dengan berbagai dampaknya dan dengan peluang untuk memberikan umpan balik segera. Selain itu, menurut Effendi (Liliweri, 1996) bahwa komunikasi antarpribadi atau komunikasi interpersonal adalah komunikasi antar komunikator dengan seorang komunikan yang efektif untuk mengubah sikap, pendapat, atau perilaku manusia yang berhubung prosesnya yang dialogis.

Selanjutnya menurut Beebe, Beebe, dan Redmond (2008) menjelaskan bahwa komunikasi interpersonal adalah komunikasi antarpribadi yang khas, komunikasi transaksional yang melibatkan pengaruh timbal balik dengan tujuan mengelola hubungan untuk lebih baik. Komunikasi interpersonal membangun hubungan dengan orang lain. Sementara itu, Johnson (Supratiknya, 1995) mengungkapkan komunikasi interpersonal membantu perkembangan intelektual, sosial, penemuan identitas diri, mampu memahami realitas di sekeliling kita serta menguji kebenaran kesan-kesan dan pengertian yang kita miliki tentang dunia di 
sekitar kita. Selain itu, komunikasi interpersonal juga menentukan kualitas kesehatan mental individu.

Devito (Suranto, 2011) mengemukakan lima aspek yang mendukung komunikasi interpersonal yaitu; keterbukaan (openess), empati (empathy), sikap mendukung (supportiveness), sikap positif (positiveness), dan kesetaraan (equality). Sementara itu, Rakhmat (2012) mengemukakan faktor-faktor yang menumbuhkan hubungan interpersonal yan baik, yaitu; percaya, sikap suportif, sikap terbuka, dan sikap asertif. Berdasarkan uraian di atas terdapat beberapa sikap yang mendukung dalam meningkatkan komunikasi interpersonal individu. Salah satunya dengan sikap asertif.

Alberti dan Emmons (2001) mengemukakan bahwa asertif adalah pernyataan diri yang positif dengan tetap menghargai orang lain, sehingga dapat meningkatkan kualitas hubungan individu dengan orang lain. Perilaku asertif mempromosikan kesetaraan dalam hubugan manusia, yang memungkinkan individu bertindak menurut kepentingan diri sendiri, untuk membela diri sendiri tanpa kecemasan yang tidak semestinya, untuk mengekspresikan perasaan dengan jujur dan nyaman, untuk menerapkan hak-hak pribadi kita tanpa menyangkal hak orang lain.

Selanjutnya Corey (2013) mengemukkan bahwa perilaku asertif adalah ekspresi langsung, jujur, dan pada tempatnya dari pikiran, perasaan, kebutuhan, atau hak-hak seseorang tanpa kecemasan yang beralasan. Kemampuan menyampaikan pikiran dan perasaan secara langsung artinya bahwa pernyataan dapat dinyatakan secara langsung jelas tanpa berbelit-belit. Jujur berarti menyampaikan pernyataan disertai dengan bahasa tubuh sesuai dengan apa yang diarahkannya. Sedangkan pada tempatnya berarti perilaku tersebut juga memperhitungkan hak-hak dan perasaan orang lain serta tidak melulu mementingkan dirinya sendiri dengan mengugkapkan perasaan dan pikiran sesuatu dengan tempat yang tepat. Menurut Beebe, Beebe, dan Redmond (2008) bahwa asertif adalah kemampuan mengutamakan kepentingan pribadi tanpa menyangkal hak orang lain. Menurut Alberti \& Emmons (2001) aspek-aspek asertif, yaitu: bertindak sesuai dengan keinginannya sendiri, mampu 
mengekspresikan perasaan jujur dan nyaman, mampu mempertahankan diri, mampu menyatakan pendapat dan tidak mengabaikan hak-hak orang lain.

Pelatihan asertif telah terbukti dalam beberapa penelitian untuk meningkatkan keterampilan komunikasi interpersonal individu. Purwanta (2012) mengemukakan bahwa pelatihan asertivitas adalah prosedur pengubahan perilaku yang mengajarkan, membimbing, melatih dan mendorong klien untuk menyatakan dan berperilaku tegas dalam situasi tertentu. Efektivitas pelatihan asertif dalam meningkatkan komunikasi interpersonal juga telah dilakukan dalam beberapa penelitian sebelumnya. Triningtyas dan Nursalim (2009) dalam penelitiannya mengamati delapan siswa di sekolah. Umumnya, siswa mengalami kesulitan dalam komunikasi asertif. Mereka cenderung untuk menjaga masalah mereka sendiri, tidak mampu untuk melampiaskan kemarahan, takut untuk memiliki pendapat, takut untuk bertanya dan menjawab pertanyaan meskipun tahu jawabannya, tidak bisa menolak permintaan teman, takut kepada guru, dan tidak dapat memulai percakapan. Namun kemudian diberikan pelatihan asertif dan hasilnya menunjukkan peningkatan yang signifikan pada keterampilan komunikasi interpersonal siswa antara sebelum dan sesudah diterapkan pelatihan asertif. Purita (2015) dalam penelitiannya menghasilkan bahwa pelatihan asertivitas memberikan pengaruh terhadap peningkatan kemampuan komunikasi interpersonal pada siswa. Terdapat peningkatan skor kemampuan komunikasi interpersonal pada siswa sebelum dan setelah pelatihan. Setelah mengikuti pelatihan siswa mengetahui cara untuk berkomunikasi secara lebih baik dan asertif, memiliki keberanian untuk mengungkapkan pendapat dan pikirannya kepada orang lain, menjadi lebih mampu menghormati orang lain ketika berkomunikasi, serta menjadi lebih mampu mengontrol emosi pada saat berkomunikasi.

Selain itu, Asrowi dan Barida (2013) dalam penelitiannya menghasilkan bahwa pelatihan asertif meningkatkan keterampilan komunikasi siswa SMA. Peningkatan komunikasi setelah diberikan pelatihan meliputi kemampuan siswa mengatakan tidak, siswa mampu berkomunikasi dalam waktu yang lama, intonasi suara yang jelas, mampu mengekspresikan pendapat dan perasaan dengan benar, 
mampu mengelola emosi saat berbicara.Adapun penelitian yang dilakukan oleh Arista (2015) menunjukkan bahwa metode assertive training meningkatkan kemampuan interpersonal siswa yang ditunjukkan dengan perubahan pola berfikir, mampu menata ucapan dan menyeleksi kata, mampu memperbaiki cara berkomunikasi, membangun hubungan yang baik, serta menghargai orang lain.

Dengan demikian, dapat disimpulkan bahwa pelatihan asertif telah terbukti meningkatkan kemampuan interpersonal dengan yang tampak dari kemampuan individu dalam menungkapkan perasaan dan pikirannya secara tegas dan jujur. Tujuan latihan asertif dalam penelitian ini untuk menyelesaikan permasalahan siswa X SMKN X Jurusan pemasaran dengan meningkatkan kemampuan interpersonal yaitu mampu berkata tidak, membuat permintaan, mengekspresikan perasaan baik positif maupun negatif serta membuka dan mengakhiri percakapan. Dalam penelitian ini, pelatihan asertif dilakukan melalui delapan sesi, yaitu:

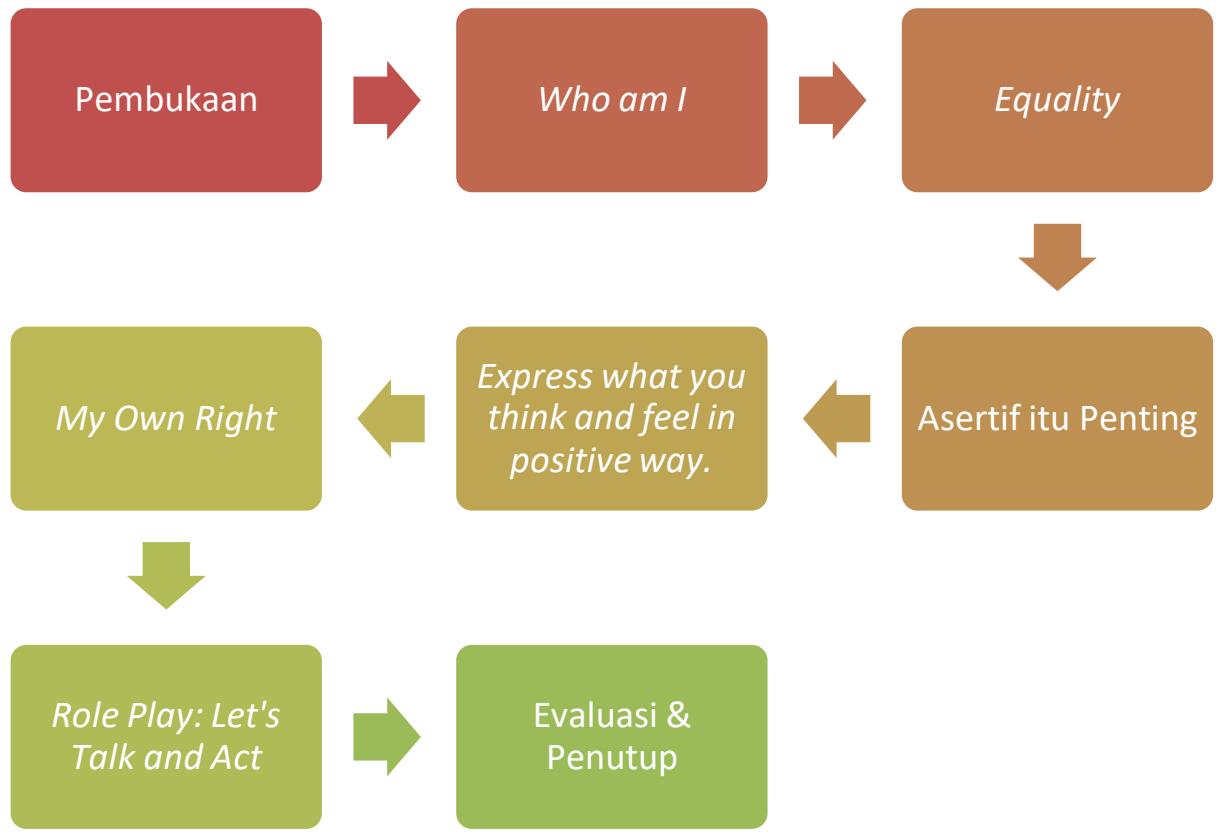

Gambar 1. Pelaksanaan Intervensi Pelatihan Asertif

\section{METODE PENELITIAN}

\section{Desain Penelitian}

Desain penelitian yang digunakan dalam penelitian ini adalah quasi experimental design. Myers dan Hansen (2002), quasi experimental design yang sederhana dibentuk kelompok perlakuanberdasarkanperistiwa, karakteristik,atau 
perilaku tertentu yang pengaruhnyaingin diteliti. Rancangan eksperimen yang digunakan dalam penelitian ini adalah nonrandomized pretest-posttest control group design.

\section{Responden Penelitian}

Responden penelitian, ini adalah siswa SMKN kelas X, jurusan Pemasaran. Responden yang terlibat dalam penelitian ini adalah 11 siswa dengan kategori keterampilan komunikasi interpersonal yang sedang.

\section{Metode Pengumpulan Data}

Metode pengumpulan data adalah cara-cara yang digunakan untuk memperoleh data guna mencapai tujuan penelitian. Pengumpulan data dalam penelitian ini berupa observasi, wawancara, FGD (Focus Group Discussion), dan skala komunikasi interpersonal diadaptasi dari Puspitasari (2012) dengan nilai realibilitas $(\mathrm{r}=0,77)$.

\section{Analisis Data}

Teknik analisis data yang dilakukan dalam mengolah data penelitian menggunakan program SPSS 16.0 for windows. Teknik analisis data yang digunakan adalah analisis statistik non parametrik paired sample t-test.

\section{Prosedur Pelaksanaan Penelitian}

Prosedur pelaksanaan penelitian dapat dijabarkan dalam bagan berikut;

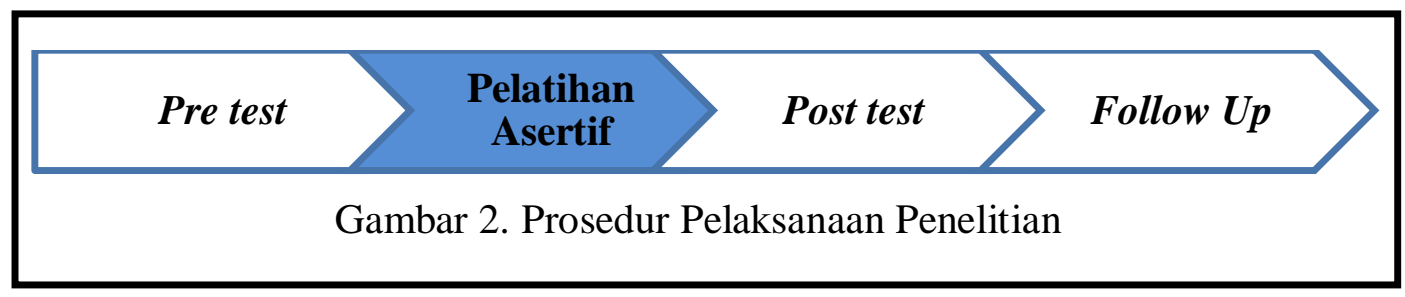

Pelaksanaan intervensi berupa pelatihan atau training dilakukan di SMKN X selama \pm 7 jam dalam sehari. Kegiatan tersebut diisi dengan berbagai materi asertif disertai dengan icebreaking dan games. Penyampaian pelatihan asertif 
denganprogram social skill training meliputi ceramah, instruksi, pelatihan, diskusi, umpan balik, permainan peran, pemutaran video, dan lembar kerja.

\section{HASIL PENELITIAN DAN PEMBAHASAN}

Efektivitas pelatihan asertif dapat diketahui dengan terjadinya peningkatan skor keterampilan komunikasi interpersonal responden penelitian padapretest, posttes dan follow up. Pengambilan data awal (pretest) permasalahan dengan menggunakan skala komunikasi interpersonal, kemudian pengambilan data post test 2 bulan setelah pretest sedangkan follow up dilaksanakan dua minggu setelah intervensi diberikan Adapun gambaran perubahan yang terjadi pada responden penelitian digambarkan dalam grafik berikut:

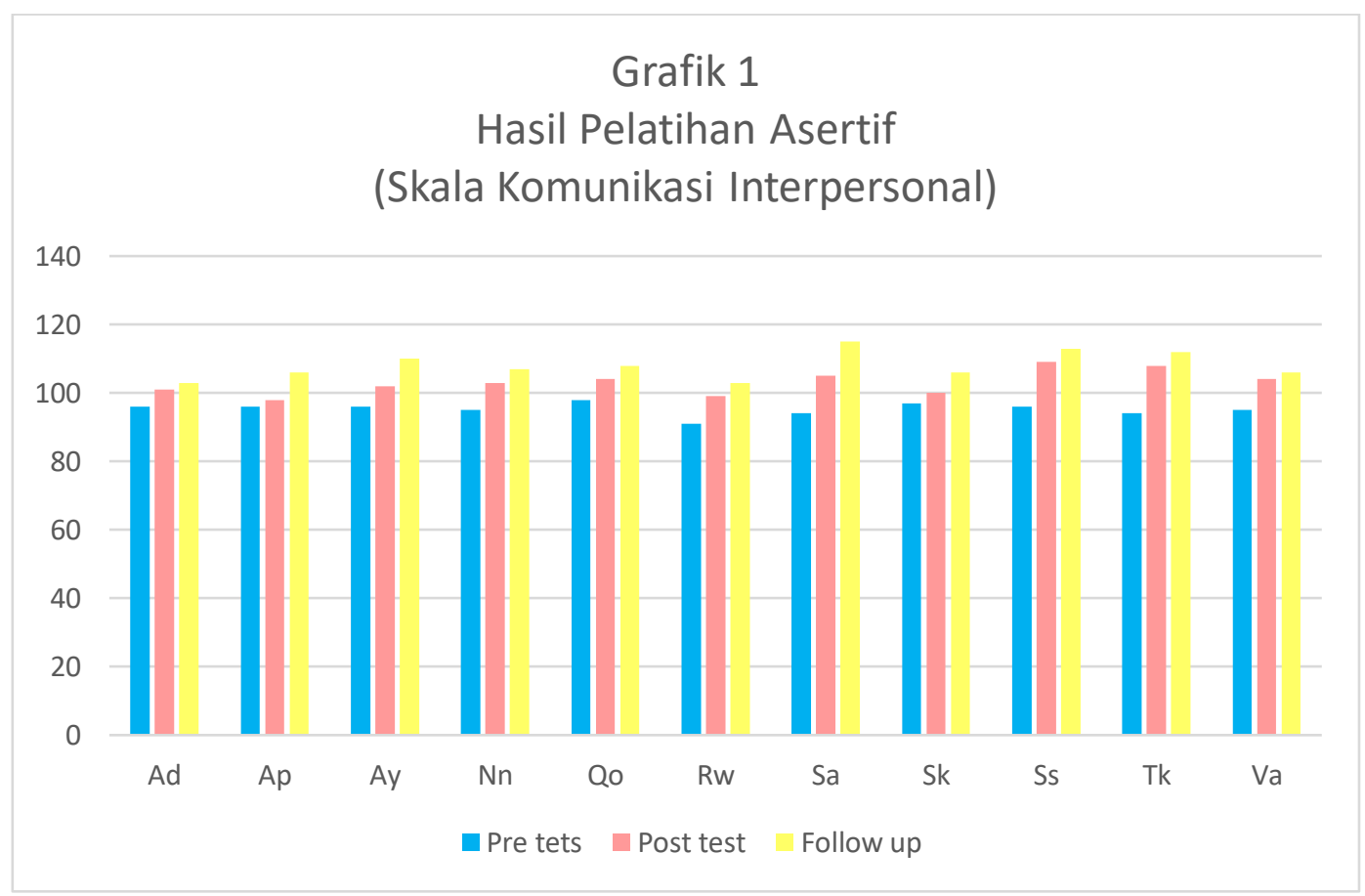

Berdasarkan hasil uji analisis statistik dengan menggunakan paired sample t-test menunjukkan bahwa ada perubahan yang siginifikan pada komunikasi interpersonal siswa X Pemasaran. Selanjutnya, hasil analisis statistik antara pre test dan post test diperoleh $\mathrm{p}=0,000(\mathrm{p}<0,05)$. Hal tersebut menunjukkan bahwa adanya peningkatan yang signifikan pada komunikasi interpersonal siswa $\mathrm{X}$ Pemasaran. Sementara itu, hasil analisis statistik antara post test dan follow up juga menunjukkan peningkatan dengan nilai $\mathrm{p}=0,000(\mathrm{p}<0,05)$. Hal tersebut 
menunjukkan bahwa adanya peningkatan yang signifikan pada komunikasi interpersonal siswa $\mathrm{X}$ Pemasaran setelah dua minggu pasca diberikan pelatihan.Peningkatan kemampuan komunikasi interpersonal siswa setelah pelatihan asertif merupakan bentuk tercapainya tujuan dari pelatihan sehingga hubungan antar sesama siswa semakin efektif dalam kegiatan di sekolah.

Secara umum, kelima aspek komunikasi interpersonal mengalami peningkatan seperti keterbukaan, empati, sikap mendukung, sikap positif, dan kesetaraan. Hal tersebut didukung dengan pelathihan asertif yang mengajarkan siswa untuk mengekspreiskan pikiran dan perasaan, meningkatkan kesetaraan hubungan, membangun kesadaran diri dan menerapkan hak-hak pribadi. Sehingga aspek komunikasi interpersonal mengalami perubahan.

Aspek keterbukaan merupakan aspek yang mengalami perubahan paling menonjol dimana secara umum peserta mengalami peningkatan dari pre test $(21,81)$ post test $(23,73)$ dan follow up $(25,18)$. Menurut Devito (Suranto, 2011) bahwa keterbukaan sangat mendukung komunikasi interpersonal dengan membuka diri, bersikap jujur, saling menghargai, menerima kritikan dan memberikan reaksi kepada orang lain. Sikap keterbukaan dapat latih dengan asertif. Menurut Alberti dan Emmons (2001) bahwa asertif adalah bentuk pernyataan diri yang positif dengan tetap menghargai orang lain. Sehingga keterbukaan dalam pelatihan asertif mengalami peningkatan disebabkan dalam pelatihan siswa diajarkan untuk mengekspresikan perasaan dan pikiran secara jujur dan nyaman sebagai salah satu cara membuka diri kepada orang lain.

Selanjutnya, sikap mendukung juga mengalami peningkatan dengan skor pre test $(21,91)$ post test $(23,27)$ dan follow up $(24,00)$. Menurut Devito (Suranto, 2011) bahwa sikap mendukung terdapat pada komitmen antara sender dan receiver untuk mendukung terciptanya interaksi yang terbuka. Peningkatan tersebut disebabkan karena dalam pelatihan asertif dimana siswa diajarkan untuk memahami diri sendiri agar mampu memahami orang lain agar komunikasi antarpribadi lebih efektif. Aspek selanjutnya adalah sikap positif dengan skor post test $(20,64)$, post test $(22,73)$ dan follow up $(23,27)$. Menurut Devito (Suranto, 2011) bahwa sikap positif merupakan aspek penting dalam komunikasi 
interpersonal dalam hal tiap orang idealnya memiliki pemikiran positif, dengan positif memandang dirinya dan orang lain. Peningkatan yang terjadi disebabkan karena pelatihan asertif memuat pengajaran kepada siswa dalam berpikir positif memandang dirinya dan orang lain melalui materi kesetaraan hubungan dan penerapan hak-hak pribadi.

Menurut Devito (Suranto, 2011) bahwa empati adalah kemampuan seseorang untuk merasakan kalau sendainya menjadi orang lain melalui memahami dan meraskan apa yang dirasakan oleh orang lain. Aspek empati juga mengalami peningkatan dengan skor rata-rata pretest $(20,36)$, post test $(21,18)$ dan follow up $(22,27)$. Aspek tersebut mengalami peningkatan disebabkan karena dalam pelatihan asertif siswa diajarkan kesadaran diri dengan mengajak siswa mengetahui dirinya dan teman untuk mengembangkan sikap saling memahami. Aspek empati adalah aspek yang paling sedikit mengalami peningkatan dibandingkan aspek lainnya.

Aspek terakhir adalah kesetaraan hubungan. Devito (Suranto, 2011) mengemukakan bahwa sebuah pengakuan kedua belah pihak memiliki kepentingan yang sama-sama bernilai, berharga, dan saling memerlukan agar informasi tersampaikan bagi kedua belah pihak. Kesetaraan mengalami peningkatan disebabkan dalam pelatihan diajarkan bagaimana siswa menyadari pentingnya kesetaraan hubungan dengan orang lain. Aspekkesetaraan mengalami perubahan skor dari rata rata pre test $(14,45)$, post test $(16,09)$, dan follow up $(16,55)$.

Pelatihan asertif yang dilakukan didasarkan oleh teori cognitive behavior. Teori tersebut menjelaskan bahwa proses kognitif menjadi faktor penentu dalam proses berfikir, merasa, dan bertindak. Pelatihan asertif menurut Corey (2013) adalah penerapan tingkah laku pada kelompok dengan tujuan membantu individuindividu mengembangkan cara-cara berhubungan yang lebih langsung dalam situasi interpersonal. Pelatihan asertif merupakan suatu usaha yang dirancang untuk memperbaiki, mengubah, atau mengembangkan sikap melalui peningkatan kemampuan asertif untuk mengurangi dampak-dampak negatif dikarenakan kurangnya kecakapan bersikap asertif atau mengajarkan keterampilan tingkah 
laku asertif melalui pengalaman. Aplikasi teori tersebut dalam pelatihan dijabarkan dalam beberapa sesi hingga folow up.

Sesi pertama yaitu who am $i$ yang berisi materi tentang pengenalan diri dan tujuan diri dengan mengenalai diri dan perspektif orang lain terhadap diri siswa. Peserta diajarkan untuk mengetahui dirinya dan teman dalam membantu mengembangkan sikap saling memahami antar pribadi. Sesi kedua yaitu equality yang berisi tentang hubungan dalam menjalin komunikasi dengan orang lain. Peserta diajarkan mengenai kesamaan posisi dalam berinteraksi sosial. Ketiga, membangun kesadaran diri dengan mengajarkan siswa untuk mengetahui kompetensi diri dalam berkomunikasi dengan mengajarkan siswa untuk mengetahui keinginan diri, mengungkapkan perasaan dan pikiran secara jujur dan nyaman kepada orang lain.

Sesi keempat, mengekspresikan diri dengan mengajarkan siswa mengenali emosi dan mendeskripsikan diri serta menyapaikan maksdu dengan beberapa bentuk asertif. Kelima, mempertahankan hak-hak pribadi yang berisi materi tentang mempertahankan hak dan kewajiban dalam berkomunikasi. Sedangkan diakhir sesi, siswa diajarkan melalui role play dan pemutaran videountuk membedakan komunikasi yang pasif, asertif dan agresif.

Adapun hasil follow up menunjukkan bahwa secara umum siswa mengalami peningkatan pemahaman tentang komunikasi yang baik dengan asertif. Siswa menyadari bahwa dengan asertif maka komunikasi interpersonal menjadi semakin efektif disebabkan karena adanya saling keterbukaan mengungkapkan pikiran dan perasaan kepada teman yang lain. Selain itu, siswa menyadari bahwa bersikap pasif menyebabkan permasalahan tidak dapat diselesaikan dan terkadang dianggap remeh oleh orang lain. Beberapa siswa kemudian bersikap asertif dalam beberapa kondisi di sekolah seperti menceritakan perasaannya kepada teman ketika merasa tidak nyaman ataupun mencoba memberitahu teman yang rebut, lebih percaya diri dalam presentasi, lebih mampu mengkomunikasikan perasaan dan pikirannya secara jujur dan terbuka. Di sisi lain, beberapa siswa mulai menyadari bahwa bersikap agresif dapat menyinggung perasaan orang lain sehingga dibutuhkan sikap asertif. 
Asertif dalam berkomunikasi menyebabkan informasi disampaikan dengan jelas dan jujur kepada orang lain tanpa menyebabkan kesalahpahaman. Menurut Devito (Suranto, 2011) bahwa komunikasi interpersonal akan efektif apabila terdapat keinginan untuk membuka diri, bersikap dan berkata jujur terhadap lawan bicara, keinginan untuk mengargai, sikap dapat menerima masukan dari orang lain, memberikan reaksi kepada orang lain serta berkenan menyampaikan informasi penting kepada orang lain. Berdasarkan hasil analisis statistik dan deskriptif pada follow up maka dapat disimpulkan bahwa pelatihan asertif terbukti mampu meningkatkan komunikasi interpesonal siswa.

Selain hasil analisis statistik, peningkatan komunikasi interpersonal siswa juga didukung dengan hasil wawancara pada respon. Siswa dalam hal ini responden penelitian mengungkapkan bahwa perubahan komunikasi disebabkan karena perubahan pengetahuan setelah mengikuti pelatihan asertif dan merasa bahwa asertif begitu penting dalam mengutarakan perasaannya, merasa bertanggung jawab menyampaikan kepada teman-teman jika tidak sesuai dengan opininya, siswa menyadari pentingnya terbuka agar mudah menyampaikan dan menerima informasi dari lingkungan, serta memahami pentingnya asertif dalam menyampaikan pendapat dengan tidak pasif maupun agresif.

\section{KESIMPULAN DAN SARAN}

\section{Kesimpulan.}

Berdasarkan hasil analisis data dan uraian pembahasan yang telah dijabarkan sebelumnya, maka dapat disimpulkan bahwa pelatihan asertif meningkatkan kemampuan komunikasi interpersonal siswa X Pemasaran SMKN X. Peningkatan yang terjadi karena adanya perubahan nilai skor dari skala komunikasi interpesonal pada siswa antara sebelum dan setelah pelatihan serta follow up yaitu dua minggu setelah pelatihan. Sedangkan berdasarkan analisis kualitatif ditemukan bahwa siswa mendapatkan pengetahuan baru dari pelatihan asertif seperti mengetahui bahwa sikap asertif adalah bentuk komunikasi yang positif, siswa mulai menyadari untuk mengungkapkan pikiran dan perasaan kepada orang 
lain, siswa berani menceritakan ketidaknyamanan pada teman, siswa menjadi lebih mampu menghormati orang lain dan juga menjaga hak-hak pribadi.

\section{Saran}

Berdasarkan proses asaesmen dan hasil pelatihan maka praktikan merekomendasikan beberapa saran sebagai berikut:

1. Pihak Sekolah.

a. Siswa. Siswa diharapkan untuk terus berlatih mengembangkan keterampilan komunikasi interpersonal yang dimiliki terutama mengasah kepekaan agar lebih berempati sesama teman-teman, guru maupun orang lain.

b. Guru. Guru diharapkan untuk terus memberikan bimbingan kepada siswa-siswa dalam menyadari pentingnya komunikasi interpersonal antar siswa di sekolah khususnya komunikasi yang asertif.

c. Sekolah. Hasil pelatihan menunjukkan bahwa adanya peningkatan kemampuan komunikasi interpersonal setelah diberikan pelatihan asertif yang berarti bahwa dengan pelatihan mampu meningkatkan kompetensi siswa dalam berkomunikasi. Sehingga, disarankan kepada pihak sekolah agar kiranya memberikan pelatihan kepada siswa untuk meningkatkan komunikasi interpersonal berdasarkan modul yang ada.

2. Praktisi selanjutnya.

a. Praktisi selanjutnya kiranya memperhatikan waktu pelaksanaan agar pelatihan berjalan efektif.

b. Praktisi selanjutnya kiranya dapat melakukan pelatihan yang sama dengan peserta yang lebih banyak lagi namun tetap mengacu pada teori dan modul yang ada.

\section{DAFTAR PUSTAKA}

Alberti, R. \& Emmons, M. (2001). Your perfect right (panduan praktis hidup lebih ekspresif dan jujur pada diri sendiri). Penerjemah Ursula G Budhitjahja. Jakarta: PT Elex Kumputindo. 
Arsita, S. D. (2015). Peningkatan kemampuan komunikasi interpersonal melalui assertive training pada siswa kelas VIII SMP Negeri 15 Yogyakarta tahun ajaran 2013/2014. Skipsi Bimbingan dan Konseling tidak diterbitkan: Universitas Negeri Yogyakarta.

Asrowi. \& Barida, M. (2013). The effectiveness of assertive training to increase the communication skill of high school students in Surakarta. Dije Vol 1.

Beebe,S, A., Beebe, S, J., \& Redmond, M., V. (2008). Interpersonal communication; relation to others. New York: Pearson.

Corey, G. (2013). Teori dan praktek konseling \& psikoterapi. Bandung: Refika Aditama

Liliweri, A. (1996). Komunikasi antarpribadi. Bandung: Citra Aditya Bakti.

Myers, A. \& Hansen, C. H. 2002. Experimental Psychology, (5th ed.). Pacific Groves: Wadsworth.

Purita, A. (2015).Komunikasi interpersonal pada siswa Sekolah Menengah Kejuruan (SMK) "X" Yogyakarta. Tesis: tidak diterbitkan. Yogyakarta: Magister Profesi Psikologi FPSB Universitas Islam Indonesia.

Purwanta, E. (2012). Modifikasi perilaku alternatif penanganan anak berkebutuhan khusus. Yogyakarta: Pustaka Pelajar.

Puspitasari, M. (2012). Hubungan antara citra tubuh dengan komunikasi interpersonal temn sebaya pada remaja putri di SMA Negeri 7 Surakarta. Skripsi: tidak diterbitkan. Surakarta: Fakultas Psikologi Universitas Muhammadiyah Surakarta.

Rakhmat, J. (2012). Psikologi komunikasi. Bandung: Rosdakarya.

Supratiknya. (1995). Komunikasi antarpribadi; tinjauan psikologis. Yogyakarta: Kanisius.

Suranto, A. (2011). Komunikasi interpersonal. Yogyakarta: Graha Ilmu.

Triningtyas, E. \& Nursalim, M.(2009). Penerapan latihan asertif untuk meningkatkan keterampilan komunikasi interpersonal siswa. Skripsi tidak diterbitkan. Universitas Negeri Surabaya. 